\title{
The Knowledge about the Sexual Development of a Child in Education of the Teachers of the Preschool Breeding and also in the Early School Education. Pedagogical Reflection
}

\author{
Beata Zięba-Kołodziej, Marzena Marzec
}

In the face of the threats associated with the sphere of human sexuality, especially of a child, it is needed to prepare the future and current teachers to help effectively to the child to develop herself/ himself in all spheres of her/ his personality. What is more, it is also very important to resist effectively the abuses and to protect the limits of her/his intimacy. The sexual abuses against the child and the sexualisation are the phenomena present nowadays in almost every latitude. The reason for their broadening favors the lack of sexual development and the lack of people prepared its processing, including the teachers. As the prominent people who have the influence over the development of the child and young generations, the teacher can become the significant group against the negative phenomena of social life and to conduce to such young people development, to make them understand their sexuality and also the differences in its experiencing. They can also form the attitude and the views free from prejudices and the reluctance, fight with the stereotypes associated with the sex and with the minority sexual groups. In order to take such actions in this area, it is needed to obtain the knowledge of the specific kind-what to teach? and how to teach? What do I need to know about myself?

Keywords: sexual education, sexualisation, the factors associated with the right sexual development.

\section{Introduction}

It is difficult to discuss with the statement that one of the determinants of public health is the mental health of the citizens It is known nowadays that not only intellectual possibilities but also practical and cooperating abilities determine the social and the technological development. What is more, the social abilities are also crucial and their accomplishment depend on our mental state. Together we can do more, and the more the different we are, the greater general social potential is. However, it is needed 
to remember that not only health and rightly developed individuals are able to get use of the - for the benefit of themselves and the others - the inner resources, serving the individual development and the social change. The healthy individuals can assist and help the other people in achieving the plentitude of their own potential. Nowadays, the health and especially the mental health represents the good for which we need to care about. To this kind of reflection induces the problems which experience not only the adults but also the children and the youth. Destructive behaviors-suicides, mutilates, addictions, and also more frequent depressions among the young people, make the situation in which more intensive actions in the field of mental health protection is needed. These actions need to be taken with the greater effort today, but it is also needed to make the plan for the future. One of the elements of this plan can be the introduction into the body outcome of the future teachers the knowledge from the area of protection of mental health, including- the sexual health. This last area is the handling of this publication.

World Health Organization emphasizes that mental health is the basis of good mood and effective functioning of a person in the society and it means much more than the lack of mental disorder; it is not only the lack of illness or lack of disability, but «the state of the entire physical, mental and social well-being»(Gromulska 2010, WHO Basic Documents 2006). Its indissoluble component is the sexual health which means the «biological, emotional, intellectual and social aspects of sexuality important for the positive development of the personality, communication and love and also for good mood associated with sexuality» (Starowicz, 1999). Sexual health involves the sexual rights, inalienable right and this right has the human being from the birth to death (Declaration of Sexual Rights of the Human Being WHO WAS, 1997).

Forming of the psyche of a child and the support of her/ his mental and sexual development should be one of the elements of upbringing and care about her/him. The growth in the entire acceptance of her/ his psychosexuality, the approval and the awareness of the coming changes in the body and in the sphere of the mentality, the knowledge of the threats associated with the anomaly of formed sexuality of other people and the awareness of cultural norms, and also the tolerance for different than her own/his own sexual orientation, are the basic tasks the education is facing with which is to help to prepare for life of young generations. The steps taken in this area should be featured with the specialised knowledge and the particular abilities of the adult people. These should be for example the ability to talk with the parents about the matters concerning the psychosexual development of the child, including her/his sexual behavior 
and also the ability to answer, sometimes even very difficult questions connected with the intimate sphere of the human being.

The changes in the social mentality concerning the way the sexuality is perceived, the stereotypes associated with women and men and the relation between them, the sex role, and also the attitude towards deviant and harmful behaviors, treated in the majority of countries as sex crime (for example: pedophilia, incest, rapes, prostitution of minors, human trafficking for sexual purposes, pornography with the minor participation) or humiliating and eliminating behaviors towards queer people, are the challenges facing the education in many countries. The children and the youth need protection also against the current harmful phenomena like «sexting» and «grooming».

In order to achieve the required safety state of children and youth, the changes should start with the adults-teachers and parents-the people who have got the great impact on the behavior and the future of the detailed groups. It goes for such bringing up which will bring the result in the change the way somebody perceives herself/himself and the others; the breeding which will learn the respect, understanding, tolerance, openness and kindness towards herself/himself but also towards the other people. Sexual education of future teachers may serve for it, as those specialists who will educate the parents and the children, I accordance with their development abilities and with the age. The peculiar meaning gains the sexual education of disabled children and youth and those who show different kind of developmental dysfunctions (Fornalik, 2017, 2002, 2014; Kijak, 2010, 2014; Koller, 2000; Jurczyk 2018; Kijak, 2014), and also the activation of the youth in the area of counteraction against sexual violence and victimization [ the reference of Panton Group], and also the education of adults and youth in the field of differences and needs of no queer people (Savin-Williams, 2011; Kowalczyk and the others; 2016; Bałuka, Tritt, 2016). We should not be afraid of this kind of education in contrast to sexualisation [which a lot of us unconsciously come under, especially the children and the youth. The question is therefore: since what age should sexual education of the children start? According to the Standards of Sexual Education- the guidelines of WHO since the early age (The Standards of sexual education in Europe. The basic recommendations for policymakers..., 2012). Therefore, these contents should be taken into consideration in the process of teacher training of the preschool breeding and early school education. 


\section{The child-the psychosexual person}

A lot of adult people perceive a child as a sexual being. Meanwhile, the sexuality comes into being already in the mother's womb. Psychosexuality of a human is being formed by the first patterns of relation or the bond between a mother (or the other significant person) and the child. The sexuality of the human being does not come with the adolescence, but with her/his very early beginnings. That is why the reason for taking care of the entire development of the child within her/his psychological sphere, seems to be obvious-we are born as the bio-, the psycho, the sexual beings and while the right socialization is being developed, we are becoming the social beings and we fulfill our roles, also those associated with the sex. The social interactions inscribe in our close relation with the significant people and they are the base for future partner relations.

Comprehensive theory which says about the human sexuality, the theory of Kernberg emphasizing the participation of a lot of different factors which influence over the sexual functioning of the human being, within the developing factors and her/his sexual activity. On every level of the development, different kind of factors make the impact on the human sexuality. The impact of these factors are broadening, they change their course and content (Beisert, 2015, p. 84-91). The sexual development is based on biology, and it is being formed by the relation with the attendant, generally with the mother and the psychosexual factors. Every stage of the sexual development, the childhood, the growing up, the adulthood has its own character. The basics of the sexuality are connected with the experience from the three first years of living, (including fetal period) (Beisert, 2015; Cierpiałkowska, Turbaczewska-Brakoniecka, Groth, 2017; Lew-Starowicz, Długołęcka, 2006). It is therefore crucial, the knowledge of the parents and the teachers in this extent. All the more that the sexual development of the human being is the period which is dynamic and nonhomogeneous. The individual stages differ from each other in respect to the sources of influences, the proceedings and the consequences. Biological, psychological and social aspects of sexuality create peculiar confusion typical only for this stage.

The duration of sexual development from 0 till the age of 12 , Kernberg divides into: prior Oedipus time, the Oedipus time, and the period of latency. The crucial impact on the sexual development of the child in the time of prior Oedipus has got the mother. She creates the inimitable relation with the child and the template for her/his further contacts with other important people: the partner and her own children. This relation should be featured with strong physical and emotional bond which qualifies the right 
psychosexual development of the child. The Oedipus period is featured with the influence of family system and also the influence of the peers over the sexual development of the child. The most important people for the child are the parents and also the peers with whom revel the sexual impression. By the child during the preschool period increases the interest towards sexuality (the lack of biological reasons for the explanation of this fact). After the rough, rebellious and dynamic Oedipus period, the period of latency is coming. The content of child's interests is transferring from the sexual sphere to social (the adaptation to the new group and taking up the school study) and among this sphere is focusing the activity of the child. At the age of 10-11 the second wave of interest of the opposite sex is taking place and the contacts with the peers become the main source of information about the sexuality and the sex roles. At the same time it can be seen the mere searching for information about the sexuality (currently the most common source of information is the Internet). It is also the period of searching the deep and strong friendship with the peers of the same sex, which is the attitude entirely normal. The age from 10 till 13 is the period of the biggest sensitivity, the embarrassment, and the discountenance among the girls. However the boys the boys close themselves up and become unkind in the personal relation. At the age of 11-12 there are seen the first indication for the sexual interest, especially among the girls (the peculiar role of the imagination, the first 'loves' to the idol). Two years later the strongest sexual impulses are manifested among the boys. The inceptive, at this time, the process of pubescence, we have inscribed in our genes. The bottom limit of sexual adolescence is the age of 10, usually among the girls it is the age from 11 to 12 and it is going slower, among the boys-the sexual adolescence starts about a year and a half later and its course is faster. The top limit of the biological adolescence (achieving the sexual adolescence) is the age of 16 . During the sexual adolescence starts the search for her/his own identity. The problems with the perceiving of her/his own body appear. There are also the complexes. It can be observed the reduced stabilization of the image of herself/himself which needs the informational and emotional support from the adults.

The knowledge about the sexual development of the child during the childhood is the essential knowledge and it fulfills the image of the human being in the entire way. Her/his development is therefore the result of different factors 'as well as of the biological ones, as the effect of the process of the organism growth, as well as of the social character, as the result of the course of learning under the influence of the stimulation coming from the surrounding' (Brzezińska, 2000). This fact can be referred to the sexual 
growth and this is why it should be taken into consideration in the education of the teachers.

\section{The knowledge of the teachers about the norm and the pathology of the sexual development of the child during the childhood period}

Therefore, the question arises about the range of teachers' learning in the area of psychosexuality of the human being. The education of the students of teachers' studies should involve among other, the issues connected with the norms and the anomaly of sexual behaviors of the children and adults. In this publication we focus on the body outcome, directed towards the recognition the sexual development of the small child and the preparation of the parents and other adults for education. In the case of small children there are three important issues: the sexual expression of the children, the auto-erotic behaviors and children erotic games. Our foregoing practice indicates that quite often, this is the knowledge unfamiliar to teachers, parents, attendants and the other adults.

The sexual behaviors (the expression) of the children are something normal in their activity and they fulfill the following functions: The cognitive, the social, and the emotional. The small children are becoming interested in the differences between the sexes and the procreation. They start to ask, at this time, often difficult questions, for example' How did I find here? Does it hurt to give the birth to the child? It starts the training of gender role and forming of cultural norms which regulate the sexual behaviors.

The characteristic for kids of 2-3 is «the play house», «the doctor play», «the hospital play»; going into the toilet with the other children, kissing of the acquainted girls/boys, hugging the adult women/men, the plays characteristic for the opposite sex, gripping the phallus during the moments of excitation, the fear or the tiredness ( it refers only to the boys and his own phallus). The children at the age of four or five show the actions described below but additionally there starts to appear the interest for the opposite sex, touching the intimate parts of the body during the presence of the other people, the peeping of the other children, adults in the bathroom, expressing the opinions about the children of the opposite sex in the negative way, showing the intimate parts of the body to the other children, the imitation of the dances of the teenagers and adults, including the plays with the thread of sexual behaviors and the love story. Additionally, among the children of age 6 and 7 , there comes up the interest towards the following issue «What are the children from?» a lot of these behaviors are treated by the parents as inappropriate, worry or even disturbed. Maybe this concern is the result of the lack of knowledge about the psychosexual development of the human being. 
It is especially difficult for the parents and the other adult people, the auto-erotic behaviors of the children (children masturbation). Maria Beisert specifies the developmental masturbation which does not bring the negative results and its aim is to gain the pleasant sensation, and the experimental masturbation (the interest, searching for pleasure), and the instrumental masturbation which is the respond for stress, pressure, unpleasant states (the sorrow, the loneliness and the boredom), or the need to attract somebody's attention to herself/himself. These last two kinds of masturbation are connected with the risk of the body injury and in the case of instrumental masturbation, there is the need for making the deeper diagnosis of the child's problems. What is more, in this case, there is the threat of making the bone up on the sexual activity, for not sexual reasons (calming down, relieving the emotional stress, gaining the attendance) and also the threat to use the defense mechanism instead of using varied remedial strategies resolving the problem.

In the experience of the teachers-the practitioners of pre-school education, are, probably, the experiences connected with the erotic children games. Imitating of the sexual activities of the adults (playing house, simulating of the sexual contact of the adults) comes from the children's curiosity and also from searching for the emotional contact and sensation as the result of the stimulation of the erogenous zone. The children imitate the peers, the older children the siblings, the parents (peeped during the intimate situation) and these games, and the other elements are hidden from the adults in the anxiety about the lack of understanding. The games are based on the mimicry not connected with the sexual situations. They give the children the excuse for the contact with the body and its exploration (playing doctor, playing hospital). Similarly as earlier, the elements of these games can be hidden from the adults. The concern of the attendants should compel the games, giving the release of the excessive emotional tension or the games which aim is to get the surrounding attention. These games contain unusual, topical strands (constraint, pain, verbal aggressiveness, the phrases which aim is to settle down the child); they can induce the fear and cause the body injury among the attendees. The games of this kind can indicate that towards the child the sexual violence is commited (Zielona-Jenek, Chodecka, 2010; Beisert 2006, 1991; Piotrowska 2018).

\section{The teachers' knowledge about the sexual violence towards the child}

The body outcome in the field of sexual education during the teachers' studies should involve such issues as the symptoms of experiencing by the child the sexual violence and her/his protection against the «bad touch». The 
behavioral symptoms which can indicate sexual abuse of the small child are, among other, such her/his behavior like: obscene words, uncommon or vulgar names of sexual organs, unusual sexual behaviors for the age, insuppressible masturbation, aggressive behaviors towards the peers, simulating of the sexual contacts (also with the usage of the toys), the drawings about sexual connotations, talking and writing in the sexual context. The symptoms that the child was sexually abused can also indicate: the attitude which is overly careful, frequent rise of anger or the bad mood, the isolation, the indifference, escape from the reality, experiencing of socalled temporary amnesia, the lack of trust, the reluctance to coming back home, the complain of the underbelly and genitals pain, sleep disorder, the nightmares, bedwetting, or the children depression. The teacher should know the risk factors of sexual violance of the child. The situation which may be conducive is the social isolation of the family and the child, marital conflicts, bad atmosphere in the family, dysfunctional attitude and also family roles, emotional and sexual immaturity of the parents, sexual disorders, the lack of sexual knowledge, the situation where a father is not the biological father, the overuse of intoxicating substances, enduring mother illness, disability of the child, the lack or inappropriate kind of education of the child and the parents (Jarosz, Wysocka, 2006).

The role of the teacher is and should be making the intervention in the situation when there is the suspicion that there is the harm done to the child. That is why they should acquire the knowledge about the ways of supporting the child, about the ways of making the conversation with her/him in the difficult situation, making the strategies about the first and the specialistic help and also about the emergency response. They should know the possible consequences of traumatic sexual experiences. What is extremely important - the teacher should be convinced about the need of the child's protection against the wronging. The child's good should not trail with the common stereotypes and beliefs putting the child-the victim of sexual abuses in such circumstances, as those one who tells the lies, confabulates, whose opinion is not taken into the consideration. The situation in which we face these mentioned symptoms should cause the teacher's concern, simultaneously he or she should remember that such situations need deeper diagnosis. The enumerated factors conducing to sexual abuse on the child, cannot necessary cause it. Analogically-some of the child's behaviors, are not always caused by the sexual abuse. 


\section{The other content of the sexual education in the education of teachers}

In the Standards of Sexual Education-the template of sexual education (The standards of the sexual education in Europe, 2008) are distinguished the areas and content devoted to children and teenagers in the respective stages of the development. The aim of the document is to reinforce the holistic sexual education by providing the children and the youth with impartial, scientifically consistent education assumed that the education which is lead this way conduce to the development of the behaviors free from prejudices, reluctance and hate which favors establishing the society in which different points of views are heard. The emphasized holistic attitude in the mentioned Standards is based on the understanding of sexuality as one of the dimension of human being. This attitude can potentially help children and young people in developing essential abilities enabling selfdetermination of her/his own sexuality and its connotations with the other areas of personality and life.

These abilities are also crucial in the protection against potential risk factors. The way to formulate the content of sexual education included in the Standards helps the template which is divided into the age groups: from 0 to 4 years old, from 4 to 6 years old, from 6 to 9 years old, from 9 till 12 years old, from 12 till 15 years old, 15 years old and more. The education is hold in 3 categories: the knowledge (relay the information about the subject), the skills (teach the child), the attitudes (help the child to develop). It is needed to remember that not all the information is intended directly for children; some part of the information should be conveyed by the teacher/ the tutor/ the attendant/ the sexual educator or the child's parents. It is important that the attitudes which do not correspond with the accepted norms; overstepping the barriers, the actions which are threat for health are also the subject to revision. Undoubtedly, there will be no mixed feeling for such content which prepares the child for her/his own prevention of intimate zone which learns what kind of adults' behaviors are inappropriate, where do we need to search for help, and who can I tell to if harm is done to me. The recommendations included in Standards and complied by the specialists in the field of sexology, psychology and education are determinants not only in the education of children, teenagers and adult people but also in the preparation the teachers for bringing up the young generations in the holistic way taking into consideration all spheres of the human being development.

The appropriate teachers' background for pursuing the sexual education (or the people for the fulfillment of the content of sexual education) and also correctly conducted sexual education from the early age 
in the company of the children and the youth and also among the parents, can represent the crucial factor of prevention against the sexualisation, understood as the circumstance in which:

1) the value of the person comes only from her/his sexual attractiveness or behavior to such extent that it eliminates the other features;

2) the person is conformed to the norm, according to which physical attractiveness (narrowly defined) means being sexy;

3) the person is being objectified in terms of her/his sexuality, so she/he rather becomes the object of the sexual abuse by the other, than somebody who is able to make her/his own actions and decisions;

4) the sexuality is imposed on the person in the inappropriate way (American Psychological Association, The Report about the girls' sexualisation, 2005) which example can be the traumatic sexualisation, who was the result of negative sexual experience acquired in the childhood (the harmful influence of the adult over the child's sexuality). The experience can restrain the psychological development of the child, lead to the child's skewed vision of intimate relation and also favor the risky sexual and self-destructive behaviors.

\section{Conclusions}

We are convinced that in the face of the social change and cultural alteration, the development of the information technology and the shrinking of the world to the dimension of 'global village' and also the negative phenomenon of social life (for example: the prostitution, the children pornography) and also the new trend associated with the sexuality-sexting grooming, cybersex, and cyber violence, tourism for the sex, the prostitutions of the minors, the addictions of younger and younger people to the pornography and to the sex or present in the everyday life sexualisation, the education of future pedagogues should be based on the comprehensive knowledge and it should also have the value of diversity. The bringing up involving assumedly all spheres of the charge's personality, should not omit the sphere of psychosexuality. It must be said that this is the part of every person and no ideologies which are against the sexuality, do not change this. It seems to be more and more significant the need for teachers' preparation for the work with the parents and with the children in the matter of discussed in this publication area. Acquiring them with the appropriate knowledge, abilities and competencies:

1) let face up to the phenomenon threatening the development,

2) can lead to forming of the individuals pursuing in the future, not only the appropriate patterns of behaviors in the intimate relations, but also those able to prevent themselves from the sexual abuses, 
3) it will lead to the people development who will take pleasure from the experienced sexuality,

4) it will form the attitude of the tolerance and the openness towards the people from the other groups than heterosexual,

In the pursue of future teachers' education in the area of psychosexuality of the human being, the following knowledge should be taken into account:

1) the knowledge about the psychosexual development of the human being, about the norms and the pathology of the sexual behaviors, about the disorders of the sexual development, the symptoms of the sexual violence and the forms of help, the cultural conditioning of the sexuality and fulfilling the sexual roles (What should a teacher know?);

2) the knowledge about the ways of relaying the knowledge about the sphere of sexuality (the methodical), contributing to the cooperation with the parents and educational work with the child (In what way can a teacher relay the knowledge?);

3) the knowledge about herself/himself, so about individual prejudices towards the sexual education, the resistance in its relaying, internalized stereotypes connected with the sex and involving the groups of sexual minorities.

\section{References}

Aktywizacja mtodziešy w zakresie przeciwdziatania przemocy seksualnej i wiktymizacji, Ponton, www.ponton.org.pl

Bałuka B., Tritt R. J., Samobójstwa w populacjach LGB - ujecie interdyscyplinarne, [w:] R. Kowalczyk, R. J. Tritt, Z. Lew-Starowicz, LGB: zdrowie psychiczne i seksualne, Warszawa 2016.

Beisert M., Rozwój psychoseksualny č̨towieka, [w:] Z. Lew-Starowič, V. Skrsypulec, Podstany seksuologii, Warszawa 2015.

Beisert M., Seks twojego drieckea, Poznań 1991.

Beisert M., Seksualnośc w y klu sycia cz̨towieka, Warszawa 2006.

Brearley G., Jak możemy to żmienic? Odpowiedzi na pytania mtodych osób niepetnosprawnych na temat ich praw, niepetnosprawności, niezale żności, seksu i innych zagadnień, Kraków 2017.

Džieci i mtodzież w internecie - koryystanie i zagrożenia z.perspektyny opiekunów. Komunikat z badan, nr 110/2015, The Centre For Public Opinion Research, Warszawa 2015, www.cbos.pl/SPISKOM.POL/2015/K_110_15.PDF.

Czub M., Zrozumieć driecko wykorzystywane seksualnie, Sopot 2015.

Cierpiałkowska L., Turbaczewska-Brakoniecka I., Groth J., Seksualność i problemy seksualne z.perspektyny psychodynamicznej, Warszawa 2017. 
Deklaracja Praw Seksualnych Cztowieka, Światowa Organization For The Sexual Health (WAS - World Association for Sexual Health), https://worldsexualhealth.net/wp-content/uploads/2013/08/DSRPolish.pdf.

Długołęcka A, Z. Lew-Starowicz, Jak sie kochać. Edukacja seksualna dla każdego, Warszawa 2010.

Filar M., Przestępstwa przeciwko wolności seksualnej i obyczajności, [w:] Z. Lew-Starowicz, V. Skrzypulec, Podstawy seksuologii, Warszawa 2015.

Fornalik I., Mam autyzm. Mam seksualność. I co dalej? Poradnik dla rodziców, terapeutów $i$ nauczycieli, Łódź 2017.

Fornalik I., Jak edukowaí seksualnie osoby z niepetnosprawnościq intelektualna? Poradnik dla specjalistów, Warszawa 2012.

Global Report on Trafficking in Persons, United Nations, New York, 2014; Report. Human trafficking in Poland. The report for 2017 r., file://C:/Users/HP/Downloads/Raport_HL_w_Polsce_za_2017.pdf

Gromulska L., Zdrowie psychiçne w swietle dokumentów Światowej Organizacji Zdrowia, w: „Epidemiological review» 2010, nr 64.

Jarosz E., Wysocka E., Diagnoza psychopedagogiczna: podstawowe problemy i rozwiazania, Warszawa 2006.

Jurczyk M., Seksualność osób z niepetnosprawnościq intelektualna, Warszawa 2018.

Kijak R., Seksualność człtowieka z niepełnosprawnościq intelektualna a rodrina, Warszawa 2014.

Kijak R., Seks i niepełnosprawność. Doświadczenia seksualne osób z niepełnosprawnościa intelektualna, Kraków 2009.

Kościelska M., Niechciana seksualność, Warszawa 2004.

Kowalczyk R., Tritt R.J., Lew - Starowicz Z., LGB. Zdrowie psychiczne i sekesualne, Warszawa 2016.

Lew-Starowicz Z., A. Dlugołęcka, Edukacja seksualna, Warszawa2006.

Lew-Starowicz Z., Podstawy sekesuologii, Warsaw 2015.

Lew-Starowicz Z., Stownik encyklopedyczny. Miłość i seks, Wrocław 1999.

Makaruk K.,Włodarczyk J., Michalski P., Kontakt dzieci i młodzieży z.pornografiq. Report of the research, The Foundation „Let's give strength to the children», NPZ, Warszawa 2017

Pilarczyk K, Analiza zjawiska kontaktu dzieci i młodzieży z.pornografia w świetle teorii oraz. dotychczasowych wyników badań, www.dzieckokrzywdzone.fdds.pl

Piotrowska K. Rozwój seksualny dzieci, 2018 (e-book).

Pospiszyl K., Przestepstwa seksualne, PWN, Warszawa 2008.

Raport Amerykańskiego Towarzystwa Psychologicznego (American Pscybological Association) na temat seksualizacji driewczqt, publication: The Association Your Matter, www.twojasprawa.org.pl . 
Savin-Williams R. C., Homoseksualność w rodzinie. Ujawnianie tajemnicy, Sopot 2008.

Stein A., Nowe wychowanie seksualne. Ciało, emocje, umyst. Dorastanie do dobrych relacji z. sobq $\mathrm{i}$ innymi, Warszawa 2018.

Standardy edukacji seksualnej w Europie. Podstawowe zalecenia dla decydentów oraz specjalistów zajmujacych sie edukacja $i$ zdrowiem, The regional Office of World Health Organisation for Europe and for Bundeszentrale fÜr gesundheitliche Aufklärung, www.bzgawhocc.de/fileadmin/user_upload/Dokumente/WHO_BzgA_Standards_

Zielona - Jenek M., Chodecka A., Jestem dziewczynka jestem chłopcem. Jak wspomagać rozwój seksualny driecka, Gdańsk 2010.

Waszyńska K., Zielona-Jenek M., Zjawisko seksualizacii jako wyzwanie dla współczesnej edukacji, repozytorium.amu.edu.pl.

WHO Basic Documents, Forty-fifth editio, Suplement, Geneva: World Health Organization, October 2006.

Włodarczyk J., Sajkowska M., Wykorsystywanie seksualne dzieci. Wyniki Ogólnopolskiej diagnozy problemu pręemocy wobec diqieci. https//fdds.pl/wpcontent/uploads/2016/05/Wlodarczyk_J_Sajkowska_M_2013 . 